\title{
Assessment of Coalbed Gas Resources in Cretaceous and Tertiary Rocks on the North Slope, Alaska, 2006
}

\author{
The U.S. Geological Survey (USGS) recently \\ completed an assessment of undiscovered coalbed \\ gas resources on the North Slope of Alaska. A mean \\ estimate of undiscovered, technically recoverable \\ resources indicates a potential for about 18 trillion \\ cubic feet (TCF) of coalbed gas.
}

\section{Introduction}

The North Slope of Alaska is a vast area of land north of the Brooks Range, extending from the Chukchi Sea eastward to the Canadian border (fig. 1). This Arctic region is known to contain extensive coal deposits; hypothetical coal resource estimates indicate that nearly 4 trillion short tons of coal are in Cretaceous and Tertiary rocks (Flores and others, 2004). Because of the large volume of coal, other studies have indicated that this region might also have potential for significant coalbed gas resources (for example, Smith, 1995; Tyler and others, 1998).
The present study represents the first detailed assessment of undiscovered coalbed gas resources beneath the North Slope by the USGS. The assessment is based on the total petroleum system (TPS) concept. Geologic elements within a TPS relate to hydrocarbon source rocks (maturity, hydrocarbon generation, migration), the characteristics of reservoir rocks, and trap and seal formation. In the case of coalbed gas, the coal beds serve as both source rock and reservoir. The Brookian Coalbed Gas Composite TPS (fig. 1) includes coal-bearing rocks in Cretaceous and Tertiary strata underlying the North Slope and adjacent Alaska State waters. Assessment units (AUs) within the TPS (from oldest to youngest) include the Nanushuk Formation Coalbed Gas AU, the Prince Creek and Tuluvak Formations Coalbed Gas AU, and the Sagavanirktok Formation Coalbed Gas AU.

\section{Resource Summary}

USGS assessments provide estimates of the volumes of undiscovered petroleum resources (oil, gas, and natural gas liquids) that are technically recoverable and have the potential to be

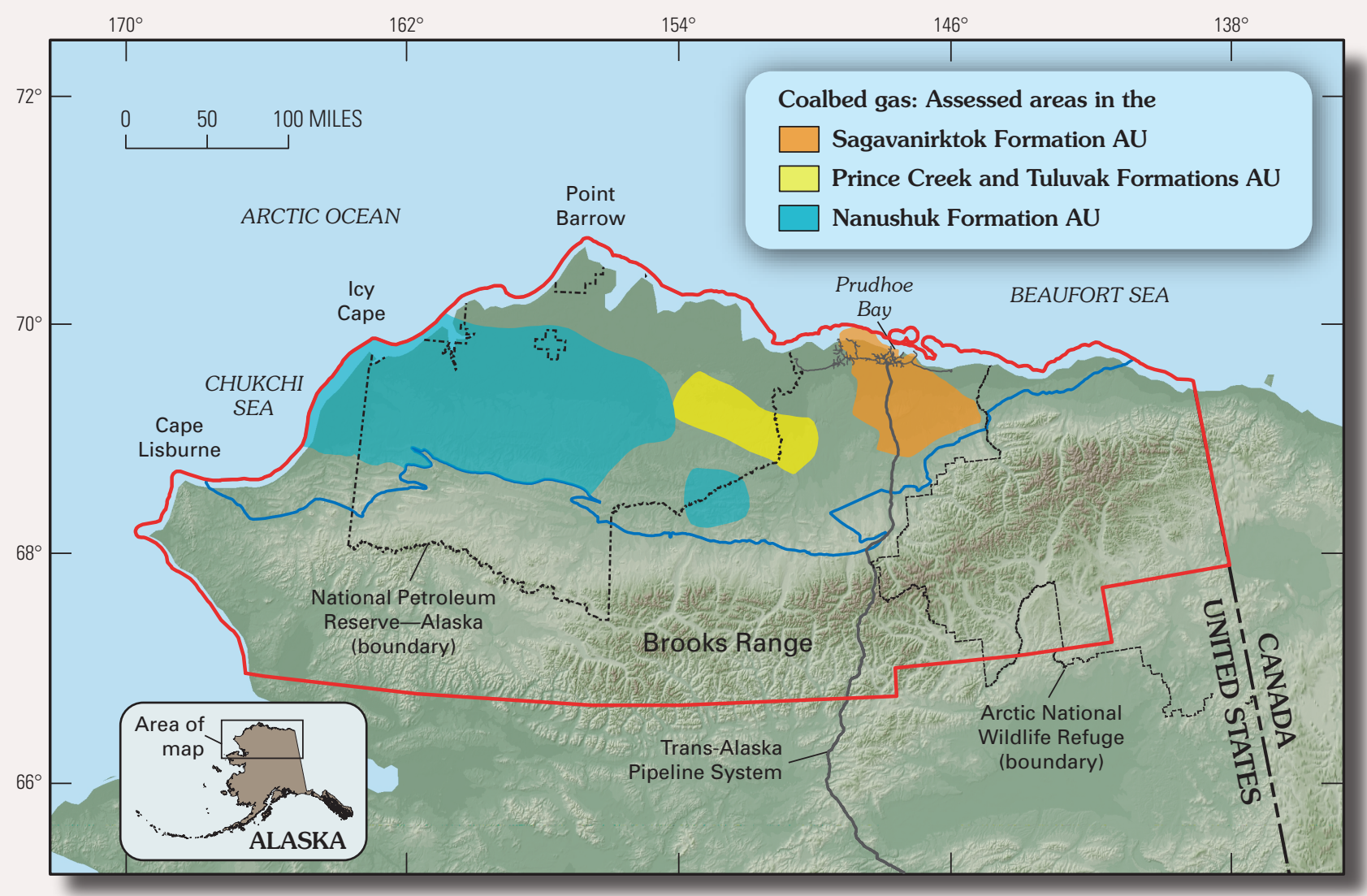

Figure 1. Boundaries of the USGS Northern Alaska Petroleum Province (red outline) and the Brookian Coalbed Gas Composite Total Petroleum system (blue outline). 
Table 1. Alaska North Slope: Coalbed gas resource assessment results

[BCFG, billion cubic feet of gas. MMBL, million barrels of natural gas liquids. Results shown are fully risked estimates. F95 denotes a 95 percent chance of at least the amount tabulated. Other fractiles are defined similarly. Fractiles are additive under the assumption of perfect positive correlation. Accum., accumulation; CBG, coalbed gas]

\begin{tabular}{|c|c|c|c|c|c|c|c|c|c|}
\hline \multirow{3}{*}{$\begin{array}{l}\text { Total Petroleum System } \\
\text { (TPS) and Coalbed Gas } \\
\text { Assessment Units (AU) }\end{array}$} & \multirow{3}{*}{$\begin{array}{l}\text { Accum. } \\
\text { type }\end{array}$} & \multicolumn{8}{|c|}{ Total undiscovered resources } \\
\hline & & \multicolumn{4}{|c|}{ Gas (BCFG) } & \multicolumn{4}{|c|}{ Liquids (MMBL) } \\
\hline & & F95 & $\mathrm{F} 50$ & F5 & Mean & F95 & F50 & F5 & Mean \\
\hline \multicolumn{10}{|l|}{$\begin{array}{l}\text { Brookian Coalbed Gas } \\
\text { Composite TPS }\end{array}$} \\
\hline Nanushuk Formation AU & CBG & 5,834 & 13,279 & 30,225 & 15,047 & 10 & 28 & 83 & 35 \\
\hline Prince Creek and Tuluvak Formations AU & CBG & 350 & 709 & 1,436 & 778 & 0 & 0 & 0 & 0 \\
\hline Sagavanirktok Formation AU & CBG & 889 & 1,981 & 4,416 & 2,231 & 1 & 4 & 12 & 5 \\
\hline $\begin{array}{l}\text { Total Undiscovered } \\
\text { Oil and Gas Resources }\end{array}$ & & 7,073 & 15,969 & 36,077 & 18,056 & 11 & 32 & 95 & 40 \\
\hline
\end{tabular}

added to known reserves. Because there is currently no production of coalbed gas on the North Slope, all assessment units within the Brookian Coalbed Gas Composite TPS are considered hypothetical. Geologic factors that influenced the resource estimates include (1) the distribution and cumulative thickness of coal beds in each AU, (2) depth of permafrost relative to coal-bearing strata, (3) thermal maturity of the coal, and (4) key structural elements (folds, faults) that might affect gas migration and entrapment. This assessment also utilized production data from wells in coalbed gas fields in the Wasatch Plateau (Utah) and the Powder River Basin (Wyoming) to gain insight into production potential that might be applied to North Slope coalbed gas wells. The Utah and Wyoming fields are considered viable analogs for assessing North Slope resources based on similarities in such criteria as coal thickness, thermal maturity, and overall geologic setting. In addition, this assessment only considered coals within $6,000 \mathrm{ft}$ of the ground surface because of the potential decrease in coal permeability with increasing depth.

Coal beds in the Nanushuk Formation Coalbed Gas AU are distributed over the largest area; cumulative total coal thicknesses exceed $200 \mathrm{ft}$ and individual coal bed thicknesses are as much as 30 ft. The Sagavanirktok Formation Coalbed Gas AU has cumulative coal thicknesses of more than $180 \mathrm{ft}$ with individual bed thicknesses as much as $35 \mathrm{ft}$. Coal in the Prince Creek and Tuluvak Formations Coalbed Gas AU is more limited in areal extent. Cumulative coal thickness can exceed $70 \mathrm{ft}$, and individual beds are as thick as $15 \mathrm{ft}$.

Of the mean total estimated undiscovered coalbed gas resources of 18 TCF in the Brookian Coalbed Gas Composite TPS, about 84 percent or $15 \mathrm{TCF}$ is estimated to be in the Nanushuk Formation. About 12 percent (2.2 TCF) is in the Sagavanirktok Formation and about 4 percent (0.8 TCF) is in the Prince Creek and Tuluvak Formations.

\section{North Slope Coalbed Gas Assessment Team}

Steve Roberts, Charles E. Barker (scientist emeritus), Kenneth J. Bird, Ronald R. Charpentier, Troy Cook, David W. Houseknecht, Timothy R. Klett, Richard M. Pollastro, and Christopher J. Schenk

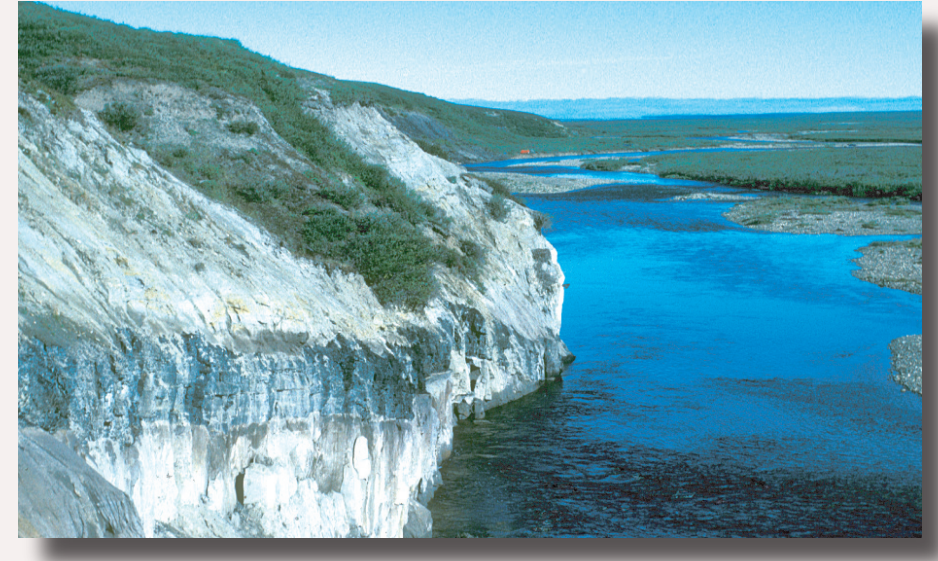

Coal bed in the Sagavanirktok Formation in the eastern part of the North Slope. Coal bed is $8 \mathrm{ft}$ thick. View is to the north.

\section{References Cited}

Flores, R.M., Stricker, G.D., and Kinney, S.A., 2004, Alaska coal geology, resources and coalbed methane potential: U.S. Geological Survey Digital Data Series 77, version 1, CD-ROM.

Smith, T.N., 1995, Coalbed methane potential for Alaska and drilling results for the upper Cook Inlet: Intergas, May 15-19, 1995, Tuscaloosa, Ala., University of Alabama, p. 1-21.

Tyler, Roger, Scott, A.R., and Clough, J.G., 1998, Coalbed methane potential and exploration targets for rural Alaskan communities: Texas Bureau of Economic Geology and Alaska Division of Geological and Geophysical Surveys Final Report (Agreement No. UTA97-0042), 169 p.

\section{For Further Information}

Geologic studies supporting the North Slope coalbed gas assessment are in progress. Assessment results are available at: http://energy.cr.usgs.gov/oilgas/noga/ or contact Steve Roberts: sroberts@usgs.gov (303) 236-7788. 